\title{
TERRITORIAL DISPARITIES IN THE ROMANIAN BANAT: ASSESSMENT, DYNAMICS AND IMPACT ON THE TERRITORIAL SYSTEM
}

\author{
Cătălina ANCUȚA \\ West University of Timişoara, Romania
}

\begin{abstract}
The article aims to evaluate the heterogeneous nature of the regional space of Romanian Banat, perceived as a developed region. The method is based on the complex paradigm of the concept of territorial disparities, which includes other concepts such as development, territory, spatial equity. The elementary disparities are analyzed by studying three categories of variables: social, economic and of life standard. In order to reveal the intraregional behavior the presented methodology used data from two census - 1992 and 2002, which permitted an analysis in two key moments: little after the change of political regime and respectively, after 10 years of transition. Global disparities are studied by calculating a global development index; according to it two types of areas were established: advantaged (above the regional average) and disadvantaged (under this average). The study of the territorial disparities - both elementary and global ones - and of their dynamics 1992-2002 led to the establishment of a territorial model.
\end{abstract}

Key Words: regional analysis, elementary/global disparities, regional model

\section{Introduction}

Banat is the cultural-historical region that in the conscience and collective memory of the Romanian people extends between the rivers Mureş to the North, Tisa to the north-west, Danube to the west and the Carpathian Mountains to the east.

Today it is a trans-border region (Fig. 1), extended on the territory of three countries: Romania (18 966 sq. km), Serbia (9376 sq. km) and Hungary (284 sq. km).

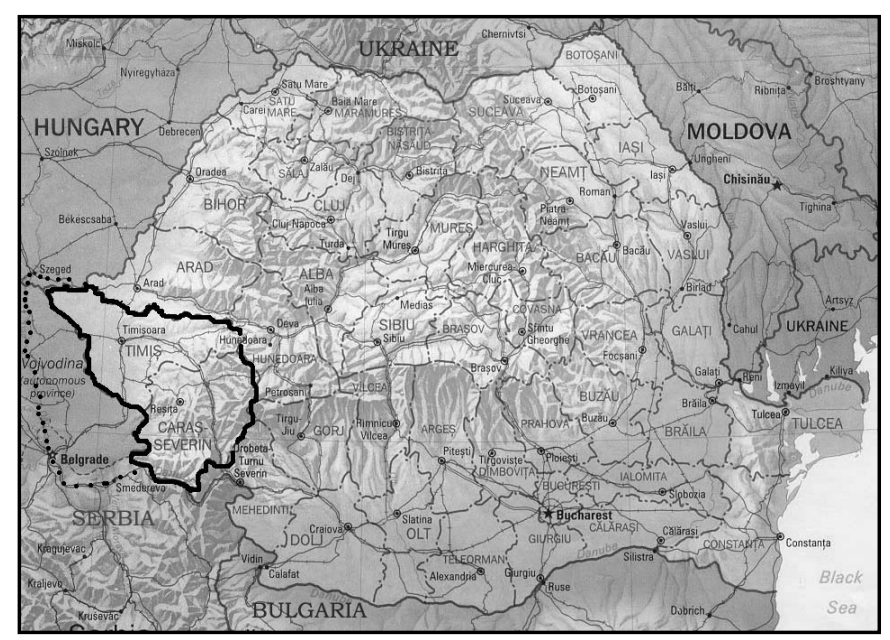

Fig. 1 - Geographical position of Romanian Banat and historical Banat (Source:

http://images.nationmaster.com/ images/motw/europe/ romania.gif, modified) 
Space of Romanian ethnic genesis, disputed in the Middle Ages between Hungarians, Turks and Austrians, the Banat is occupied by the Austrians at the beginning of the $18^{\text {th }}$ century (Sîrbovan, 1998).

Personal province of the House of Habsburg for nearly one century, Banat has been an experimental space for the mercantile theories of the time. This privileged status generated technology transfer, know-how infusion and foreigner flows, all of these generating an active, multi-ethnic and multi-religious environment and a market economy adapted to the demands of the foreign markets (Ancuța, 2007). The intercultural model of taking from the "other ethnic" only what is best together with peaceful coexistence is a major coordinate for the Banat territory (Neuman, 1997; Gavreliuc, 2001), and it has been maintained even under political regimes that were less favorable (annexation to Hungary at the end of the $19^{\text {th }}$ century).

Banat becomes part of Romania after the First World War, in a period when it experiences demographic modernization. The involution of the population from natural causes is accompanied by emigration flows, towards USA in particular, event that brings later a capital infusion, during the interwar period, Banat being nicknamed "Romania's California".

The instauration of the communist regime, after the Second World War, brought a powerful hit to the way people lived in Banat for which private property represented a guarantee of capital accumulation through profitable work. Nationalization and the rigors of communism led to the emigration of German ethnics and not only, taking with them traditions and culture. The economic preoccupations of the regime have concentrated on resource exploitation and heavy industry, which privileged the area of mountain Banat. The previous poles, with complex functionality, created over time, continued to be dynamic, profiting by centripetal flows from rural space, which has been striped of it's substance - private owning of land and responsible administration of resources. The urban space is equivalent to industrial function, while the rural space is emptied.

After 50 years of communism, the political changes started in 1989, find the villages underpopulated and with aged population, mostly incapable of administrating their development. After the political factor was removed from their functioning, the towns in Banat had different evolutions, in which functional complexity had a strong point. The centers of extractive and heavy industry, already under masked decline before 1989, collapsed as the state retreated its support.

Nowaday territorial system of Romanian Banat is the result of the accumulation of all these evolutions, different in rhythm and substance.

Romanian Banat represents $7.9 \%$ of the country surface and concentrates approximatively $5 \%$ of the country population (1065766 inhabitants, according to the 2002 census). The population density is inferior to the national average, i.e. $56.19 \mathrm{inh}$. $/ \mathrm{sq} . \mathrm{km}$ against $91 \mathrm{inh} . / \mathrm{sq}$. km. The share of urban population is superior to the national average: $64.6 \%$ against $53,3 \%$ (in 2002). The 21 towns form an urban system more developed then in other Romanian regions but, nevertheless, unbalanced in terms of size or urban polarization (Fig. 2, Table 1).

Romanian Banat is one of the most developed regions of the country in terms of regional GDP (Lefter, Constantin, 2009) and quality of living and thus a favourite traditional destination for inter regional migration (Trebici, Hristache,1986; Rey et al., 2002).

Nevertheless, the regional space is not homogeneous in terms of performance. 


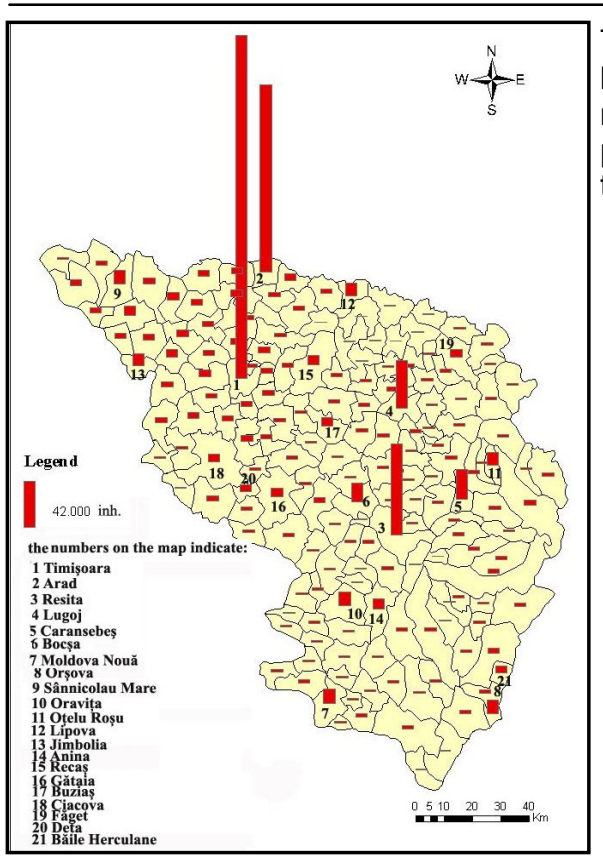

Fig. 2 - The repartition of population in Romanian Banat
The study of territorial disparities at intraregional level aims, thus, to reveal these differences intraregional that could affect the coherence and perfomance of regional system on medium and long term.

Table 1

Towns of Romanian Banat, by categories of size (2002)

\begin{tabular}{|r|l|}
\hline $\begin{array}{c}\text { Category of size } \\
\text { (according to the } \\
\text { number of } \\
\text { inhabitants) }\end{array}$ & \multicolumn{1}{|c|}{ Towns } \\
\hline$>200000$ & Timişoara \\
\hline $100000-199999$ & Arad \\
\hline $50000-9999$ & Reşița \\
\hline $20000-49999$ & Caransebeş, Lugoj \\
\hline $10000-19999$ & $\begin{array}{l}\text { Jimbolia, Lipova, Oțelu } \\
\text { Roşu, Oravița, Sânnicolau } \\
\text { Mare, Orşova, Moldova } \\
\text { Nouă, Bocşa }\end{array}$ \\
\hline$<10000$ & $\begin{array}{l}\text { Băile Herculane, Deta, } \\
\text { Făget, Ciacova, Buziaş, } \\
\text { Gătaia, Recaş, Anina }\end{array}$ \\
\hline
\end{tabular}

Source: 2002 Census of population and housing

\section{Materials and Methods}

The study of territorial systems differentiation is relatively new in Romanian geography, geography which - deprived by its social and practical valence for a long period of time practiced exhaustive description of territorial entities (Ancuța, 2001). Thus, we consider necessary to establish the theoretical and methodological endeavor of the way towards the study of territorial disparities.

Disparities always existed. Traditionally, the study of heterogeneous space had the objective of delimiting the homogenous portions, regions, in studies with idiographic characteristics.

Under the influence of regional science and in the context of the time - defined by the cold war, the confrontation of the two political and economic systems, post-colonialism and the decline of the third world, urban explosion, demographic increase (Benko, 1998) - disparities have become a frequent subject in the studies regional geography from the second half of the $20^{\text {th }}$ century, both because the existence of disparities (as of the equalizing tendencies) has specific effects in the functioning of the territory - and so its differentiation - and because inequality (under it's social aspect) is a violation of the ethical rules (Dramowicz, 1985).

Considered sometimes even necessary (Bolton and Hiks, cf. Coffey, 1982), disparities are in general - in the present context of promoting concepts like equity, equality, spatial justice, human rights - a reason for concern and the object of analysis that precede the policies that have a spatial component. 
The preoccupation for disparities is included in that for regional development and is the first obligatory step for studies on improving territorial cohesion. The approach has an important voluntary component, which presumes detecting the solutions for eliminating disparities.

The definitions found in dictionaries for the term "disparity" are not much different: disparity names an inequality, difference, lack of resemblance, of harmony.

In geographic acceptation, territorial disparity refers to an inequality that is "felt, perceived and lived as an injustice" (Brunet, Ferras, Thery, 1992, p. 150). This inequality can correspond to a difference in level in several domains (economic, social, cultural etc.). Disparities come into attention if they have an impact (quantitative or qualitative, positive or negative) on the functioning of territory and economical development (Aydalot, 1985). Disparities are evaluated necessarily in comparison with an implicit reference. The disparity marks deviation from a norm, or rule.

The paradigm of the concept includes concepts such as: spatial justice, equality and equity, development, territory as a system (Nir, 1990; lanoş, 2000; Hagget, 2001; Cocean, 2002).

In the territory taken as a system:

- the quantification of the the subsystem's components differences and their comparison to the norm that represents the average for the territorial system allows the revelation of elementary or functional disparities;

- the quantification of performance differences of the subsystems and their comparison to the average performance of the territorial system means the illustration of territorial or global disparities.

Elementary disparities can suggest elements of structure and inter-conditioning that can be useful in the study/explaining of global disparities.

The combining and switching from one level of analysis to another resolves the dilemma profound study - surface study/ extension and concentration (Watson, 1978)/large scale small scale/ national - local/ big - small (Ferras, 1992), the continuous change of the scale allows the disclosure of micro, meso and macro scale interference.

The study of territorial disparities implies the use of time in a more dynamic sense than genetic (Dauphiné, 1979) i.e. to reveal the multiple temporalities and their articulation, to identify the spatial events (EPEES, 2003; Elissalde, 2003) or the simple fluctuations, to analyze an adequate period of time, in order to observe the tendencies, in a prospective manner.

In the context of the development of quantitative geography, the conceptualization of the territory and the revealing of the multidimensional character of the development process, the studies on territorial disparities have diversified their methodological and theoretical instruments, so that we can distinguish:

- $\quad$ studies that present the spatial distribution of different indicators, that reflect one aspect or another of development, starting from a model or not and choosing/not choosing a global approach at the end (based on the methods of multi-criteria analysis) (Muntele, Groza, Țurcănaşu, 2002);

- $\quad$ studies that consider that the "individual good" is essential and in consequence analyses the "standard of life" or the "welfare", considered to be concepts with 
integrating character and studying their variations (Racine, 1988; Di Meo, 1998);

- $\quad$ studies that start from defining a complex indicator, and based on that, they diagnose the state of the territory, using the results for a prospective analysis.

As a conclusion, disparities are deviations from a norm (Aydalot, 1985), which is the average level of development of the territorial system.

The multidimensional aspect of the development process, together with the relational characteristic of the information in the system, indicat as suitable to identify some categories of variables in the light of the features considered to be efficient, the analysis not being able to consist of an exhaustive inventory of elements with the sole aim of an illusive objectivity (Vallega, 1996; Bourdieu, 1984).

If the regional level hides the cleavages, then the level of micro scale becomes indicated, because it records the unbalanced effects in the system fastest.

A sequential approach is useful to reveal the structure of the system, while studying the evolution through time reveals the behavior of components.

The heuristic approach - taking into account the theories that explain the emergence and perpetuation of disparities - is important, but the prospective approach - leading to the processes that rebalance the region - is essential (Brunet, 2001; Eckert, 1996).

In conformity with the general practice and the complexity of the concepts of "territory" and "development", the study concentrated on three categories of elementary indicators (lanoş, 1997):

- $\quad$ to evaluate the state of the economy, there are: turnover/capita (AFA), unemployment (SOM), percentage of employees in the active population (SAL), physiological density (inhabitants/agricultural hectares);

- $\quad$ to evaluate the social and demographic situation, there are four indicators: the intensity of depopulation (DEP); the percentage of population working in agriculture (AGR); percentage of old population (over 60 years of age/total population) (BAT); percentage of high school graduates in the over 12 years of age population (LIC);

- differentiations in life standard are analyzed through two indicators: inhabitable area (sqm/person) (SUP) and the number of telephones at 1000 persons (TEL).

The steps in analyzing territorial disparities were:

- measuring the elementary disparities by analyzing the individual variables, at commune and town levels, to determine their "weight" in the emerging of global disparities, their convergence or divergence, in order to appreciate their role in increasing or decreasing global disparities;

- measuring global disparities - on the base of a global development index calculated at commune and town levels - rending evident the two fundamental types of areas in relation with the norm: advantaged areas (above regional average) and disadvantaged areas (under the regional average).

The time factor is important in consequence, the presented methodology has been applied using two censuses: 1992 and 2002 that represent two key moments: just after the withdrawl of communist regime, respectively after 10 years of transition. The SWOT analysis of the identified areas was also useful for the establishement of space typology, which reveals the 
state of the system. The analysis of the so defined regional model permits the identification of solutions to maintain or reaffirm the coherence of the system.

\section{Results and Discussions}

The study of elementary disparities. Disparities elementary analysis was performed according to the following algorithm: dispersion analysis, spatial transposition, identifying of possible explanatory factors and analysis of trend evolution.

Human capital disparities. The percentage of high school graduates from the active population (LIC) is a measure of the level of education and is considered symptomatic for the competitive capacity of a territory (Nordstrom, 1996), starting from the premise that a high school diploma is for an employer a guarantee of the essential qualities of an employee, in the context of the dynamic society of today: adapting capacity, opening towards permanent formation, self organizing spirit and teamwork spirit, interior motivation, implication in the task.

The 1992 (Fig. 3) and 2002 (Fig. 4) maps of this variable are structured on rural - urban: the highest values corresponds to cities, followed by the areas surrounding the cities and those alongside access ways, the values decreasing as the distance from these increases.

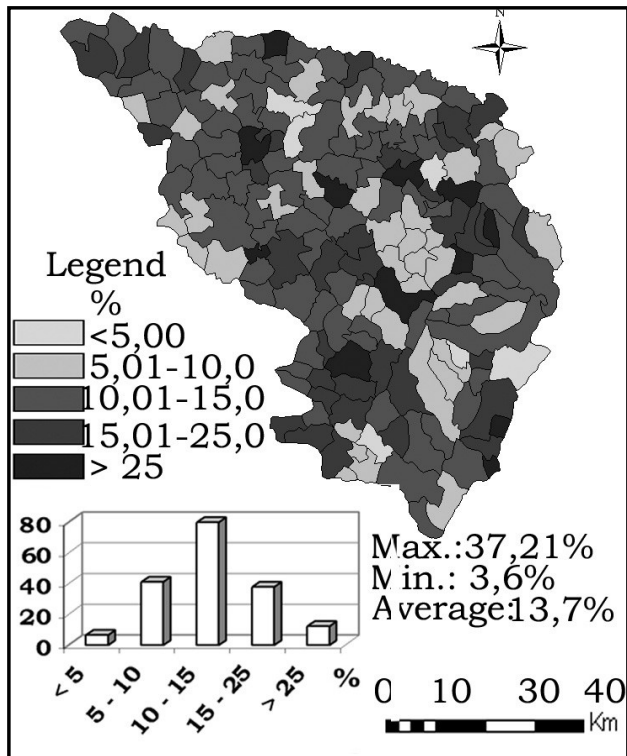

Fig. 3 - The percentage of high school graduates from the active population (LIC) 1992

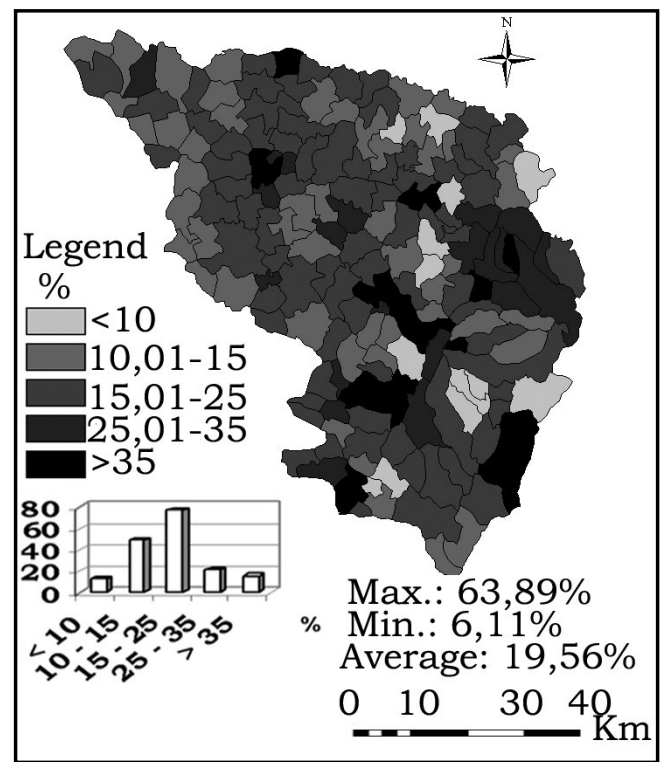

Fig. 4 - The percentage of high school graduates from the active population (LIC) 2002

The percentage of old population (above 60 years of age) of the total population (BAT) reflects the pressure on the active population and the vigor of the population as a development resource.

In 1992, the small values correspond to cities or rural settlements with industrial function (Fig. 5). 
In 2002, the dispersion remains important, a movement of the center of weight towards the superior classes can be noted; an interregional dis-balance can be perceived in space, as the south-east is strongly aged, because of natural causes and the absence of centripetal flows (Fig. 6).

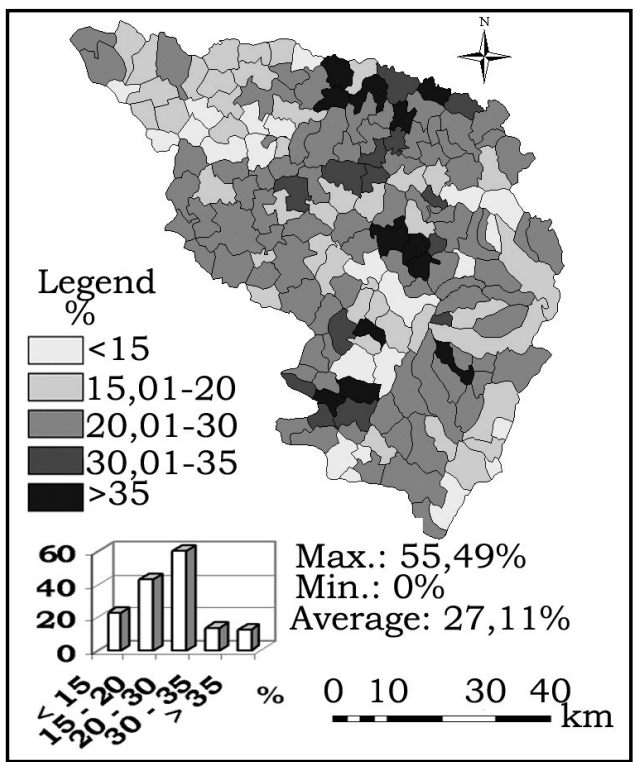

Fig. 5 - The percentage of the old population (BAT) 1992

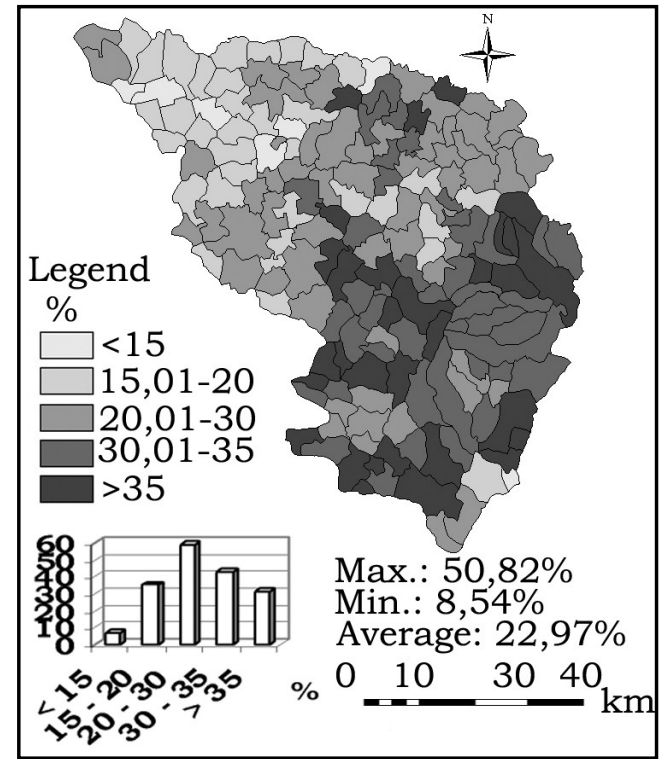

Fig. 6 - The percentage of the old population (BAT) 2002

The comparative analysis of the characteristic intervals of dispersion (quartiles), suggests a convergence tendency (the role of this indicator in creating intra-regional disparities is decreasing).

The intensity of depopulation (DEP), calculated as a ratio of the population at two successive censuses, indicates the stagnation of the population.

In 1992, the map is explained in relation with the existence of centers of economic polarization and their interconnection axes, respectively of areas with weak urban polarization (Fig. 7).

The 2002 map shows the favorable situation of the region's north-west, but a less heterogeneous situation at the whole region level (Fig. 8).

To appreciate the role of the variables analyzed above in the evolution of regional disparities, we have analyzed the simple indicator of dispersion - the variation coefficient - which permits the comparison of the dispersion of different variable distributions expressed in different measure units; it is the percentage ratio between the standard deviation and the arithmetical average (the more close to 0 , the more homogenous the collectivity) (cf. Jaba, 1998) (Table 2).

Thus, the biggest intra-regional differences are due to the LIC variable - level of education - for which the tendency of divergence is increased, while the DEP (depopulation) presents a statistical community that is very homogenous and with a convergence tendency. 


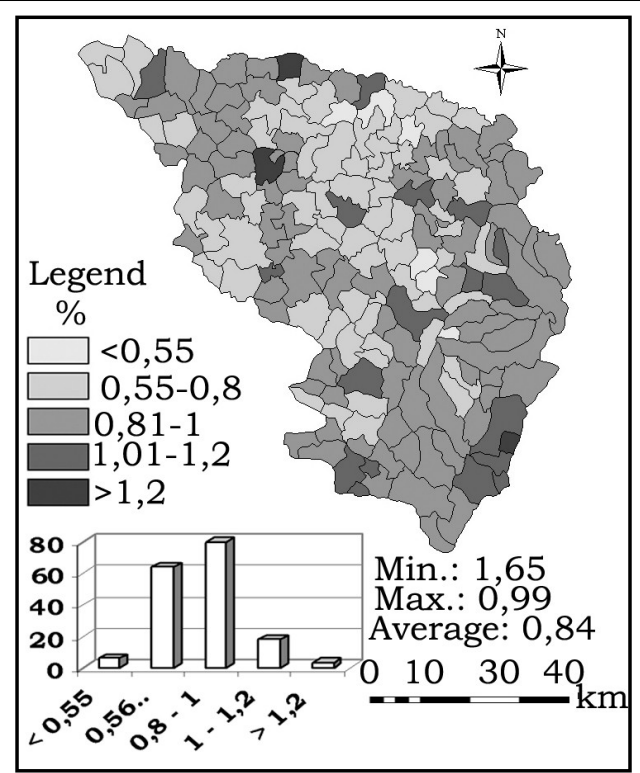

Fig. 7 - Depopulation ratio (DEP) $1977 / 1992$

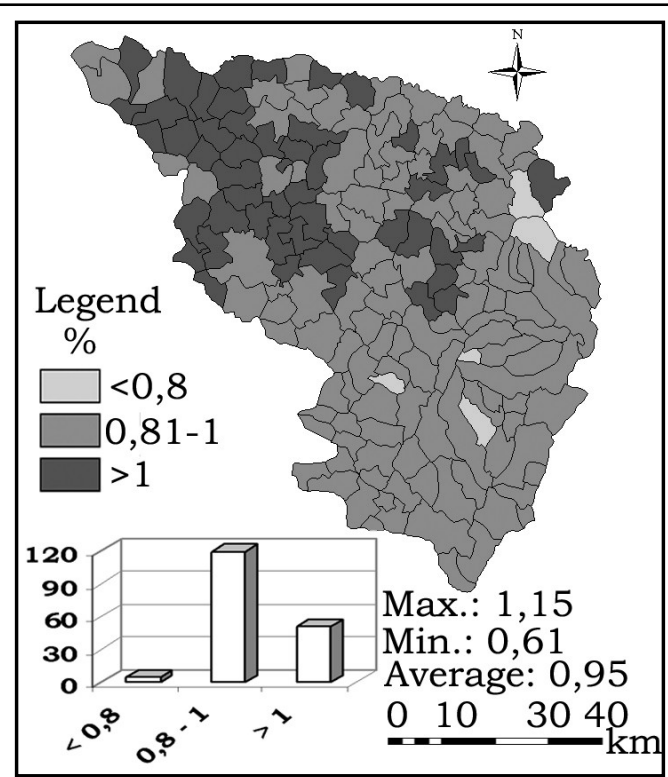

Fig. 8 - Depopulation ratio (DEP) $1992 / 2002$

The variation coefficients of variables LIC, BAT and DEP

\begin{tabular}{|l|r|r|}
\hline \multicolumn{1}{|c|}{ Variable } & \multicolumn{2}{c|}{$\begin{array}{c}\text { Variation coefficient } \\
\text { in 1992 }\end{array}$} \\
\hline LIC & $43,48 \%$ & $48,1 \%$ \\
\hline BAT & $32,78 \%$ & $29,76 \%$ \\
\hline DEP & $17,85 \%$ & $7,6 \%$ \\
\hline
\end{tabular}

Source: calculated data

Social and economic development disparities. Unemployment rate (ŞOM) and its intra-regional variations is a suggestive measure of social equilibrium, because the integration of active population in economic activities is an initial condition of its prosperity.

For the year 1992 the values present a great dispersion. Spatially, the regional pole and its immediate area are distinguished, with values inside the average interval.

In the north/western part of the region, small towns and their polarization areas have values above the average due to the social effect of industrial de-structuring. The south-eastern part, for which state support continued until 1997-1998, is below the regional average (Fig. 9).

In 2002, the unemployment rate has even bigger intra-regional disparities. This time, the situation is favorable in the north-west - and critical in the south-east (Fig. 10).

The analysis of the percentage of active persons in agriculture (AGR) indicator starts from the premise that a high percentage of people working in agriculture, thus in an activity with low 


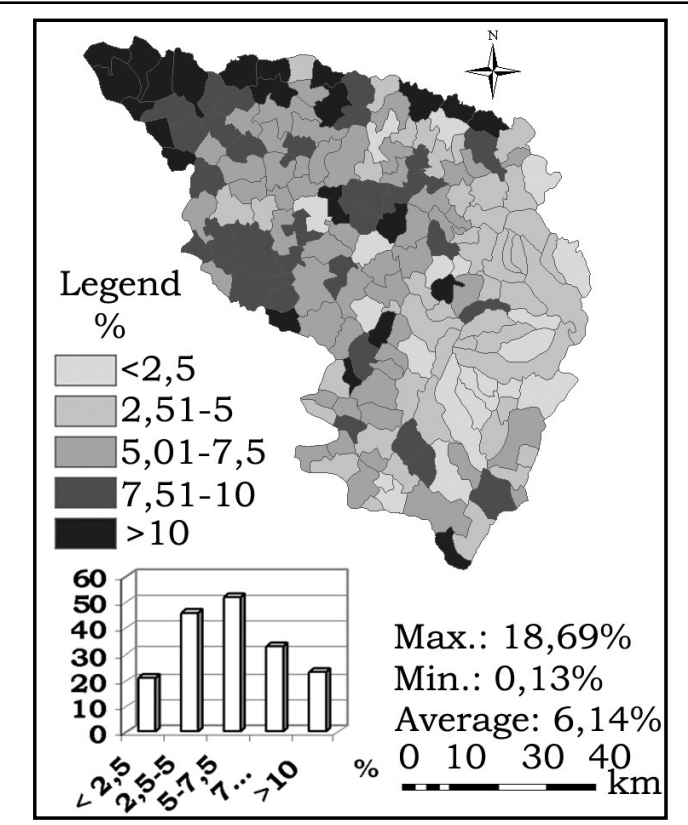

Fig. 9 - The unemployment rate (SOM) 1992

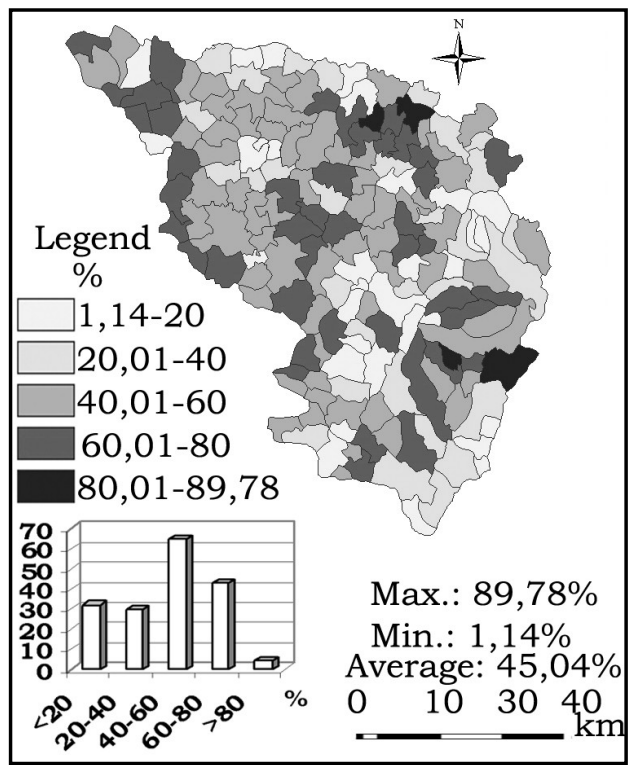

Fig. 11 - The percentage of active persons in agriculture (AGR) 1992

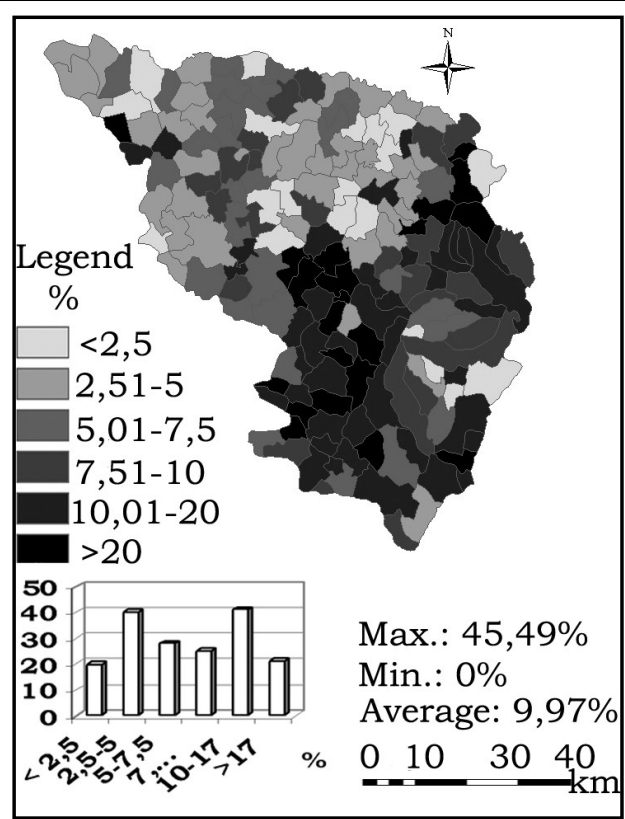

Fig. 10 - The unemployment rate (SOM) 2002

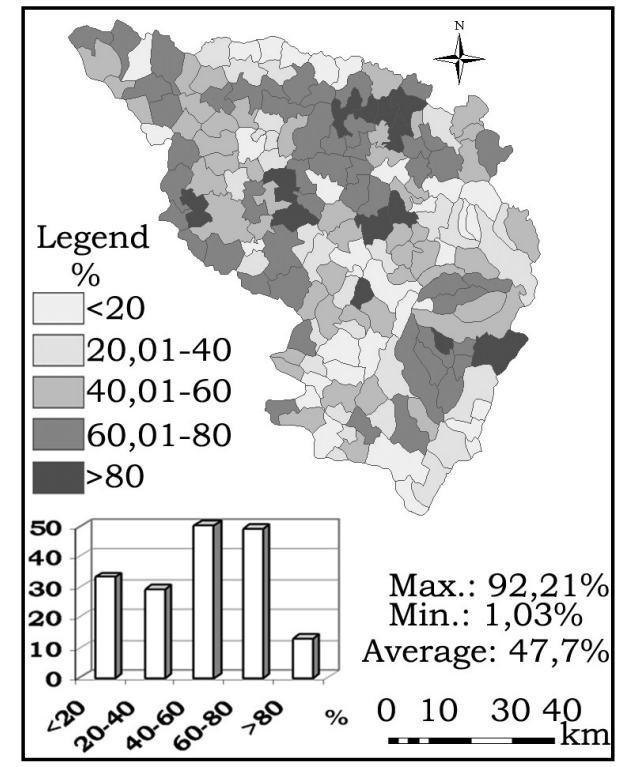

Fig. 12 - The percentage of active persons in agriculture (AGR) 2002

added value, leads to a lower competitiveness of the territory and is correlated with a modest productivity. 
The region presents contrasting situations both in 1992 and in 2002.

The repartition in frequency classes shows the high share of the upper classes. The most significant evolutions are tied to the increase in importance of agriculture as a field of work for the inhabitants of the region (Fig. 11 and Fig. 12).

The increase of the dispersion of values and thus of the intra-regional disparities generated by the AGR variable is well shown by comparing the average of intervals that are characteristic for dispersion (Table 3).

Table 3

The distance between the characteristic intervals of the variable AGR and the tendency of evolution in the 1992-2002 decade

\begin{tabular}{|l|r|r|r|r|}
\hline $\begin{array}{c}\text { The } \\
\text { characteristic } \\
\text { intervals }\end{array}$ & $\begin{array}{c}\text { The average of } \\
\text { the characteristic } \\
\text { intervals in 1992 }\end{array}$ & $\begin{array}{c}\text { \% from the } \\
\text { regional average } \\
\text { (regional average } \\
\mathbf{1 9 9 2 = 1 0 0 \% )}\end{array}$ & $\begin{array}{c}\text { The average of } \\
\text { the characteristic } \\
\text { intervals in } \\
\mathbf{2 0 0 2}\end{array}$ & $\begin{array}{c}\text { \% from the } \\
\text { regional average } \\
\text { (regional } \\
\text { average } \\
\mathbf{2 0 0 2}\end{array}$ \\
\hline $1^{\text {st }}$ decile & $4,29 \%$ & $9,52 \%$ & $3,2 \%$ & $6,7 \%$ \\
\hline $10^{\text {th }}$ decile & $78,01 \%$ & $173,2 \%$ & $83,54 \%$ & $174,98 \%$ \\
\hline $1^{\text {st }}$ quartile & $13,03 \%$ & $29,58 \%$ & $12,29 \%$ & $25,74 \%$ \\
\hline $4^{\text {th }}$ quartile & $70,66 \%$ & $156,88 \%$ & $77,07 \%$ & $161,43 \%$ \\
\hline
\end{tabular}

Source: calculated data

Turnover/capita (AFA) is an expression of the way in which interact the elements that form the energy of the system, i.e. human and financial capitals.

In the year 1992, this variable introduces a major intra-regional differentiation: the biggest values are concentrated in north-west, in a linear way, alongside some convergent axes towards the urban centers. The smallest are in the south-east of the region - vast area of heavy industry artificially sustained by state subventions (Fig. 13).

The year 2002 reveals the emphasis of intra-regional disparities. Spatially, one can observe the obliteration of the intra-regional dichotomy north-west- south-east and the generalization of differences structured on urban - rural criteria.

The biggest diffusion power of the economic dynamism belongs to the regional pole, around which can be found the largest area with turnover values superior to the regional average (Fig. 14).

The analysis of the variation coefficients of social-economic development variables reveals the fact that in general these are responsible for important intra-regional differences. The biggest intra-regional disparities which have become even more accentuated in the analysis interval are those regarding unemployment and turnover (Table 4). 


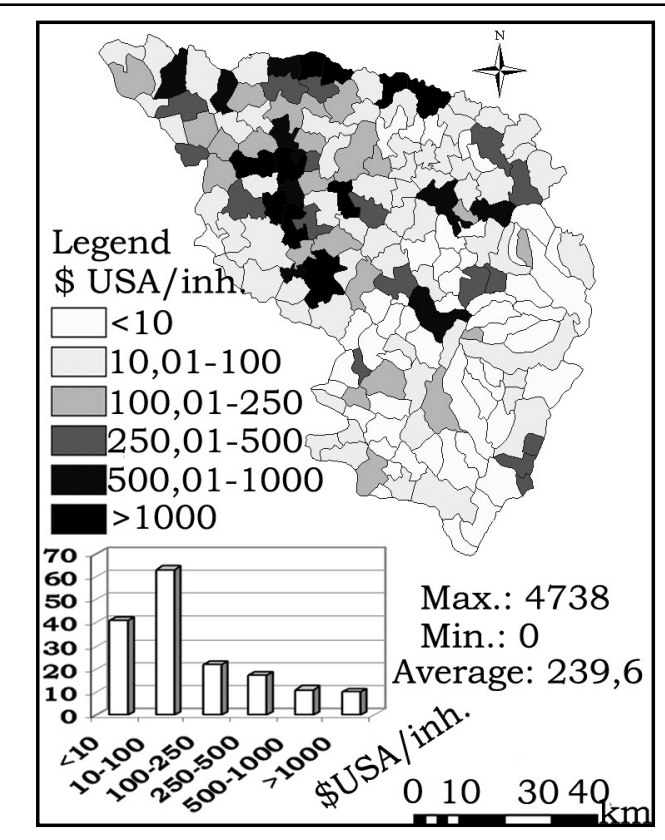

Fig. 13 - Turnover/capita (AFA) - 1992

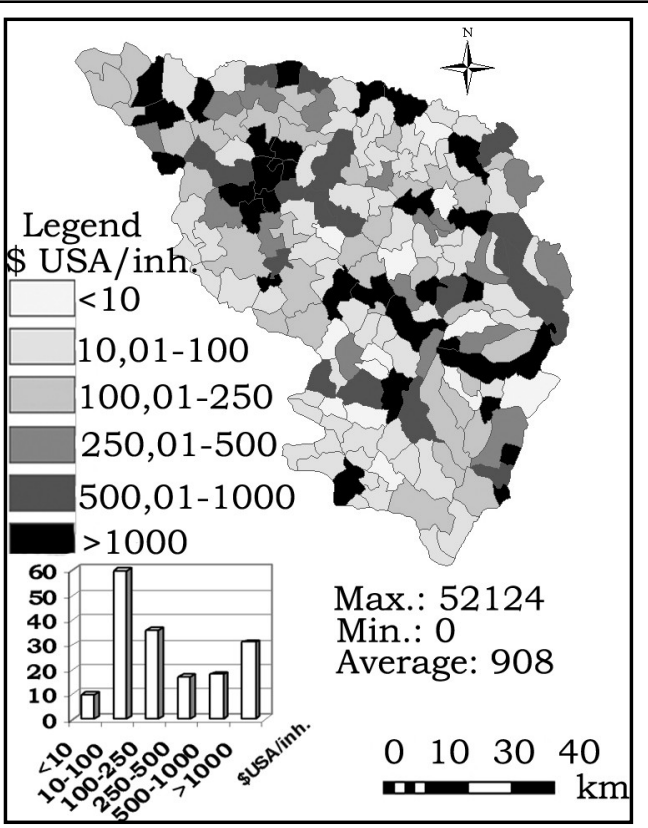

Fig. 14 - Turnover/capita (AFA) - 2002

The variation coefficients of variables SOM, AGR and AFA

Table 4

\begin{tabular}{|l|r|r|}
\hline \multicolumn{1}{|c|}{ Variable } & Variation coefficients in 1992 & Variation coefficients in 2002 \\
\hline SOM & $53,25 \%$ & $85,95 \%$ \\
\hline AGR & $49,06 \%$ & $51,94 \%$ \\
\hline AFA & $232,67 \%$ & $447,66 \%$ \\
\hline
\end{tabular}

Source: calculated data

Disparities regarding quality of life. In relation with the social geography practice, the statistical data and the objective of the present analysis, the analyse concentrated on the degree of connection to the fixed phone network, which reflects the need to interact and communicate, and the inhabitable area/person, which would correspond to the need of home security (Maslow, cf. Popa, 1999).

The degree of connection to the fixed phone network presents big differentiations at the intraregional level this indicator. The values above the average correspond to the big cities and polarization areas (Fig. 15 and Fig. 16).

The indicator of inhabitable area introduces small differentiations at intra-regional level, given the importance of traditional housing, including in towns (Fig. 17 and Fig. 18).

Thus, the analysis was refined by correlating the dynamics of the inhabitable area with that of population in the decade 1992-2002. 


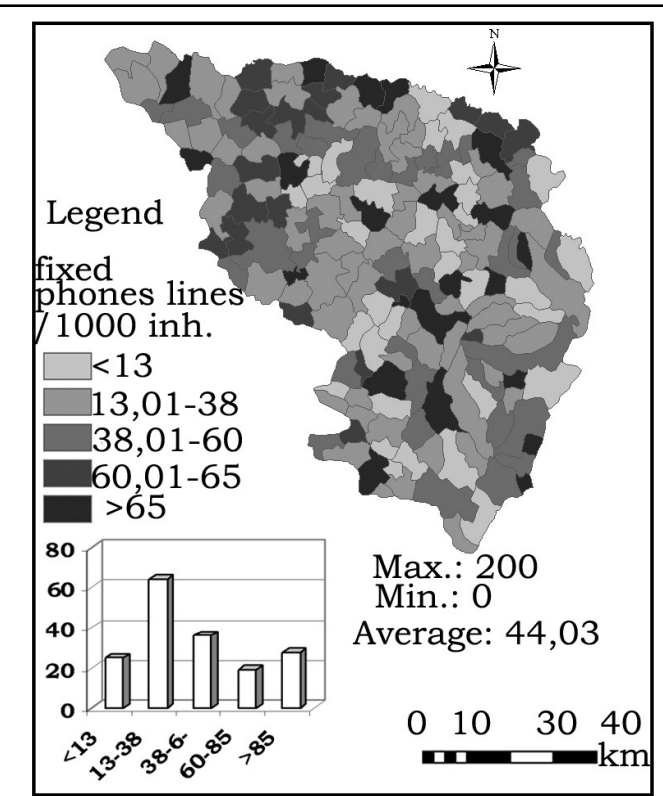

Fig. $15-$ The degree of connection to the fixed phone network (TEL) 1992

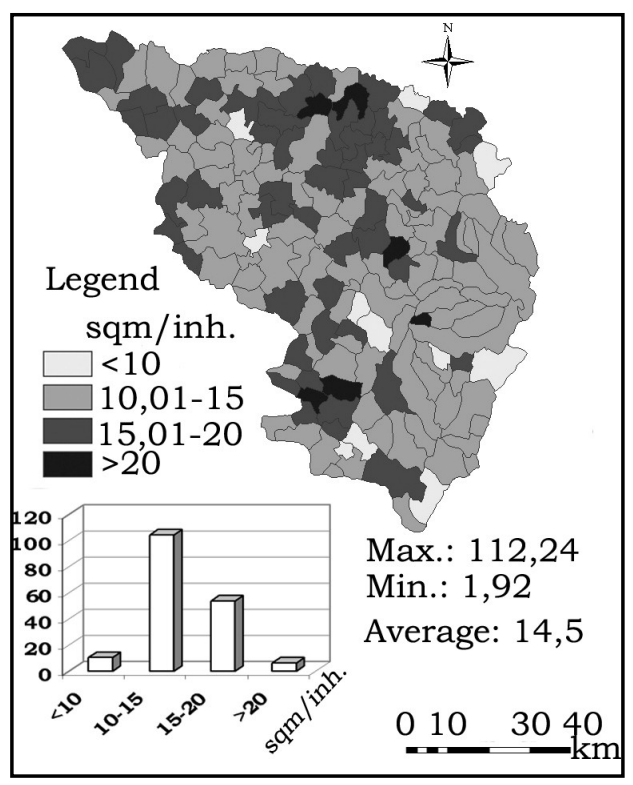

Fig. 17 - The inhabitable area (SUP)-1992

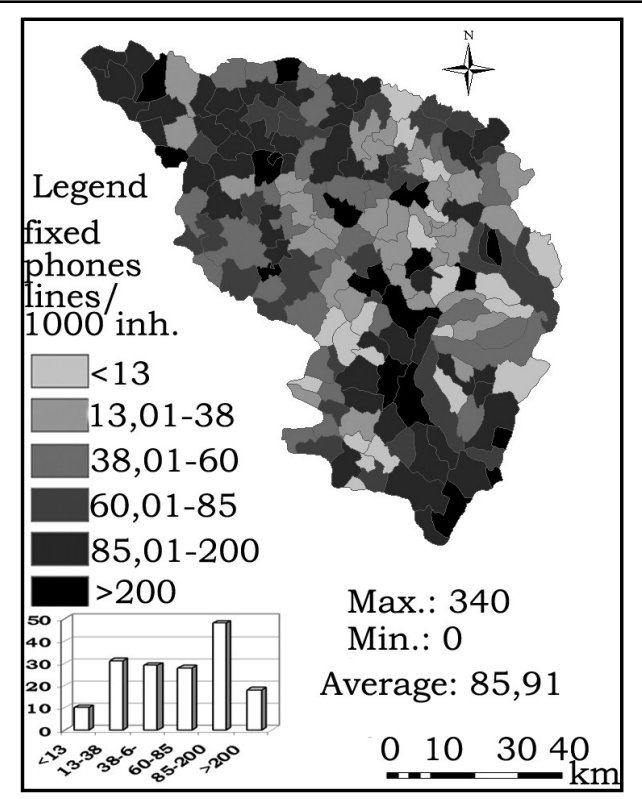

Fig. 16 - The degree of connection to the fixed phone network (TEL) 2002

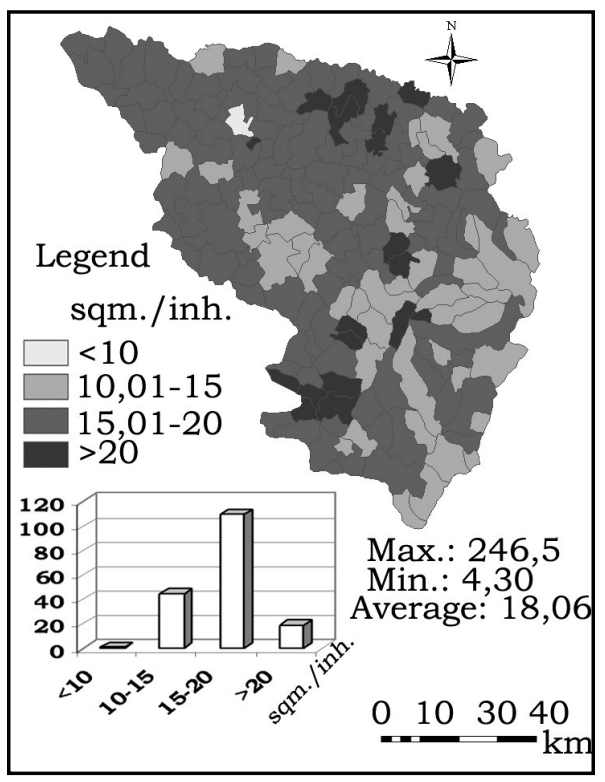

Fig. 18 - The inhabitable area (SUP)-2002

The following 6 different situations emerged:

- $\quad$ areas where the increase of inhabitable surface and the increase of the number of 
population are direct proportional (Fig. 19-T1);

- $\quad$ areas where the increase of inhabitable surface is much more emphasized than that of the population (the new inhabitants are urban citizens recently moved in suburban villages without changing their residence documents) (Fig. 19- T2);

- $\quad$ areas where the dynamics of the inhabitable surface is much more emphasized than the decrease of the population (this indicates an expansion of the already existing houses and consequently an improve of living standards) (Fig. 19- T3);

- $\quad$ areas where the population decreases highly but the inhabitable surface increases due to building of secondary residences (Fig. 19- T4);

- $\quad$ areas where the population increases, but not the inhabitable surface, which indicates a worsening of the living conditions due to financial incapacities (Fig. 19- T5);

- $\quad$ areas where the population decreases as well as the inhabitable surface, situation characteristic to the degrading of the apartments of the bloc of flats of the repulsive industrial centers or of the individual houses of the elders without families or descendants (Fig. 19- T6).

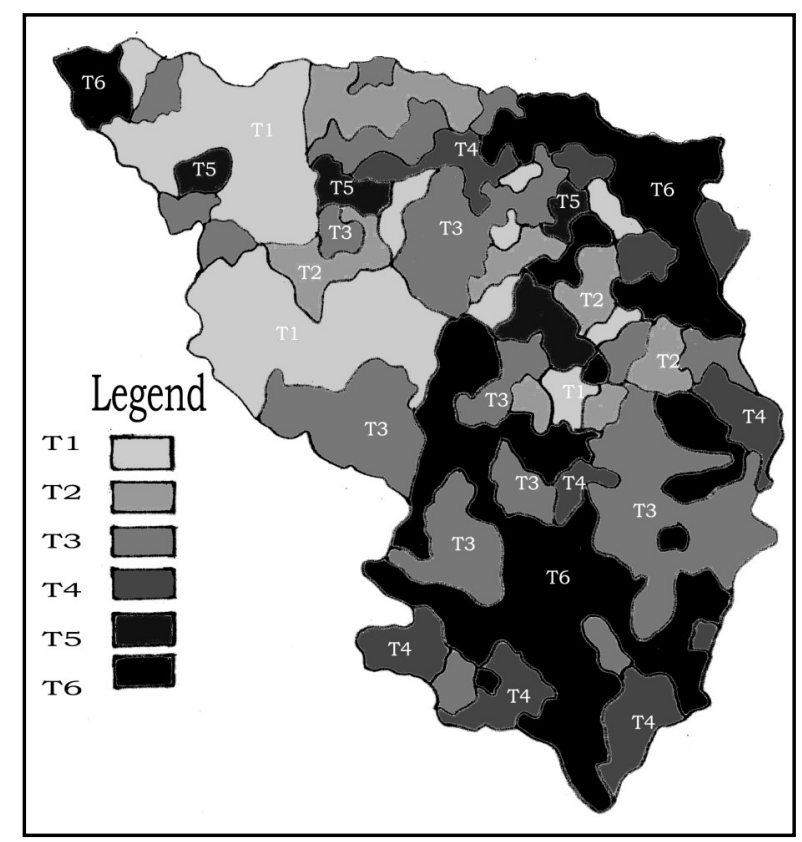

Fig. 19 - Types of correlations between the dynamic of inhabitable surface

and the dynamic of population in 1992-2002
Global intraregional disparities. Global disparities have been quantified by calculating the INDEZV - global development index -, based on the standardized values of the elementary variables.

INDEZV $=50+14$

(AFA+SUP+LIC+TEL+DEF+SAL-DEPAGR-BAT-SOM)/10 (lanoş, 1997),

where: AFA: turnover/capita, SUP: inhabitable area (sqm/person), LIC: percentage of high school graduates in the over 12 years of age population, TEL: number of telephones at 1000 persons, DEF: physiological density (inhabitants/agricultural hectares), SAL: percentage of employees in the active population, DEP: intensity of depopulation, AGR: percentage of population working in agriculture, BAT: percentage of old population (over 60 years of age/total population), SOM: unemployment ratio.

The analysis has been made for the years 1992 and 2002, considering that this decade (a transformational one, sense Walerstein, 1998) offers the possibility to observe the reaction of the spacial structures to the transition period, the strong components of the system and possible reorganization tendencies.

In 1992 the dispersion of the INDEZV values was moderate. The distribution of values shows an asymmetry which at space level means the concentration of the highest values in a small number of settlements, mostly cities, including the surrounding communes that are 
economically and socially dependent on the cities, but also rural settlements with industrial function (Fig. 20).

The majority of statistical units present values inferior to the regional average, but no less than $90 \%$ of it, covering the majority of rural space.

In 2002, the average level of development for the region is almost unchanged, revealed by an almost stationary average: 50 . There is a slight tendency to diminish the extreme values. Spatially, the evolutions are towards de-structuration of some areas and the rising of others (Fig. 21).

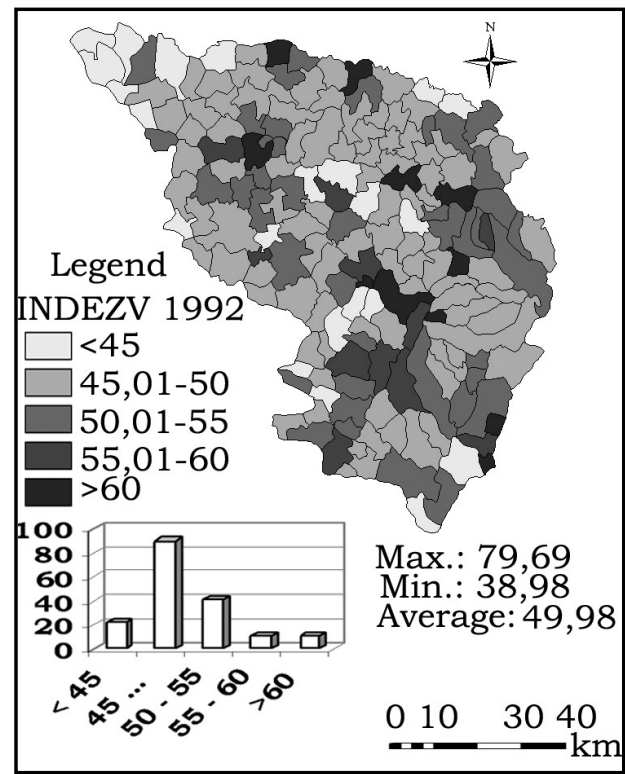

Fig. 20 - Global development index 1992

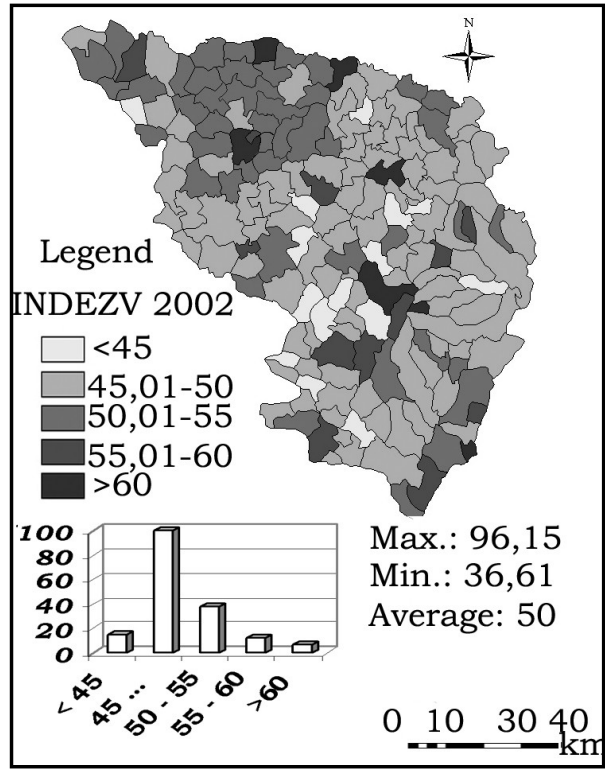

Fig. 21 - Global development index 2002

Thus, the areas that are above regional average are situated to the south and east of Banat, as the effect of the withdrawal of state subventions for heavy industry. On the other hand, urban centers that have begun transition to the market economy as soon as the years 1990-1992, have had ascending trajectories and have been capable of creating diffusion areas of their growth. The smallest values of INDEZV 2002 are found in the mountain region $-50 \%$ and hill region $-33 \%$, where rural spaces have shown very few cases of functionality capable of inducing a development above the regional average.

The statistical values of the 2002 INDEZV index have imposed two categories of areas, in relation with the average level of regional development -50 : advantaged areas, with INDEZV superior to the regional average and disadvantaged areas, with INDEZV inferior to the regional average.

Taking into account the elements revelated in the former analysis of elementary disparities and of intraregional behaviour in the 1992-2002 decade, a spatial typology has been established.

The advantaged areas split into the following, based on their behavior and role inside the 
system:

- an effervescent area, including the regional pole; through its demographic weight, economic diversity and dynamics this area is a real engine of the territorial system, "carrying" area, through which the area is connected to complex external flows and which also has an important role in assuring the competiveness of the region at a supraregional scale;

- $\quad$ an area in crisis where traditional activities collapsed and economic revival signs are modest;

- an affirmation area, which although affected by economic involution that is inevitable in the case of political regime change and the shifting from centralized regime to a free competition one, has managed in the 1999-2002 interval to straighten itself out, putting to good use the resources it has, in tight relation with the effervescent area, from where the demand for tourism in special, comes from.

The disadvantaged areas have been classified based upon the relations that they have with the advantaged areas and the problems that through their gravity determine their placement in this category and can form obstacles in their development. The typology for these areas is as follows:

- $\quad$ profound rural areas: areas with average and high degree of isolation, with weak connections between settlements, poorly polarized by urban centers, and in risk of social service de-structuring, in which agricultural production is mostly destined for their use, and are generally disconnected from the evolutions of the rest of territorial system;

- $\quad$ integrated rural areas: they have a better position in the system and develop capital flows towards the other components, but especially towards the effervescent area, their potential being affirmed in the context of the effervescent area's needs; even if it is presently a partially used potential, recent evolutions prove the existence of opening and flexibility that are necessary - sometimes in a small amount, but any sign of revival is important - for creating an area capable of decisional autonomy on a long term;

- $\quad$ agricultural areas are somewhat situated at a distance from the major connection axis of the system or at a distance from the effervescent area, they occupy an intermediary position between the types mentioned above, have a function directly bound to the productivity of the soil, without any signs of putting to good use of other elements.

The hierarchy of urban centers shown in the model has been based on the polarization capacity or the types of relations - cooperation, subordination, competition and indifference between cities (lanoş, Humeau, 2000).

The typology that has been established for the urban poles inside the territorial system of Romanian Banat has taken into account the results of these researches, as well as the INDEZV values ant their evolutions in the analyzed interval (Fig. 22).

The territorial model puts in light some needed measures for rebalancing the region:

- the sustained development of some urban central points is needed in order to stimulate the diffusion of development in the disadvantaged areas;

- putting into good use the complex potential (e.g. tourism, agriculture, forestry, thermal water, traditional handmaded products) in order to stop the centrifugal demographic flux and to change the repulsive character of some rural areas;

- improvement of intraregional connectivity;

- the inter-communal projects and the efforts for reviving the regional identity and civil responsibility stimulating the inhabitants to assume the role of territorial actor would also be 
essential for maintaining the system as a functional one.

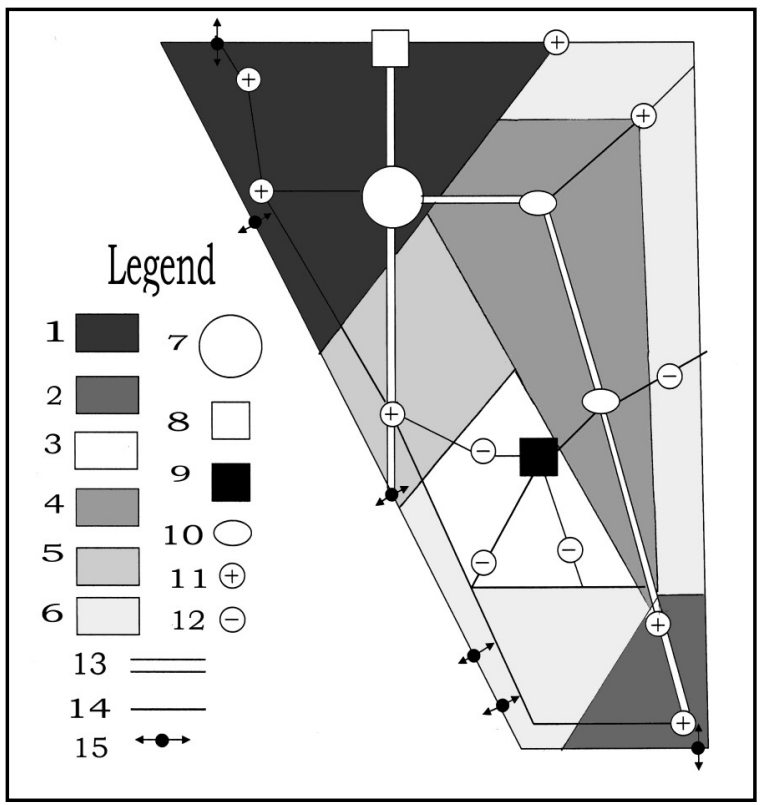

Fig. 22 - The territorial model of the Romanian Banat

(Legend: 1: effervescent area, 2: affirmation area, 3: area in crisis, 4: integrated rural areas, 5: agricultural areas, 6: profound rural areas, 7: regional pole with complex functions, 8 : subregional pole with complex functions, in growth, 9: urban pole with complex functions in decline, 10: urban pole with mixt functions, 11: local pole, in growth, 12: local pole in decline, 13: international road, 14: national road, 15: crossborder point)

\section{Conclusions}

The geographic space is by excellence heterogeneous and geographers have always sought to reveal its diversity.

More than that, the study of territorial disparities enables to measure how much the different components of the system deviate from a norm and to show - in a diachronic analysis - the repercussions on the functioning and performances of the territorial system.

Romanian Banat, recognized historical region, is still not a conventional region, as long as it is constructed in terms of represented and perceived space and has limits that correspond to the area of extension of the feeling of devotion shown by its inhabitants.

With all these, the functioning of the region in the context of communism and later in the years of transition towards a market economy influenced the coherence and outlined some differences.

The study of the territorial disparities - both elementary and global ones - and of their dynamic 1992-2002, emphasized some advantaged and disadvantaged areas and led to the establishment of a territorial model which offers a clear synthesis of the territorial issues in this region.

The clearest dichotomy is that between the regional pole (city Timisoara) with its surroundings - the most dynamic and the most receptive at the same time - and the rest of the region.

If this fact is positive from the perspective of regional competitiveness, the coherence, is, on the 
other hand, so much more affected.

The established regional model offers a clear synthesis of the territorial issues in this region and also guides in finding some needed rebalancing measures.

Thus, the study of territorial disparities proves its efficency as first obligatory step for studies on improving territorial cohesion.

The approach has an important voluntary component, which presumes detecting the solutions for eliminating disparities.

\section{Acknowledgement}

This paper presents partial results obtained in the frame of research grant ID 1074, contr. 971/2009, PN II, Program "IDEAS" financed by the National Council for Scientific Research in Higher Education. The author acknowledges to anonymous reviewers for their thoughtful suggestions and comments.

\section{References}

ANCUȚA C. (2001), Considerații privind abordarea disparităților teritoriale în studiile de geografie, Geographica Timisiensis, vol. X, 1, Timişoara p. 85-93.

ANCUȚA C. (2007), Studiul geografic al disparităților teritoriale în Banatul românesc, Editura Mirton, Timişoara.

AYDALOT P. (1985), Economie régionale et urbaine, Edit. Economica, Paris.

BENKO G. (1998), La science regionale, PUF, Paris.

BOURDIEU P. (1984), Homo academicus, Édition de Minuit, Paris.

BRUNET R. (2001), Le déchiffrement du monde, Ed. Belin, Paris.

BRUNET R., FERRAS R., THERRY H. (1992), Les mots de la géographie. Dictionnaire critique, GIP- Reclus et La documentation Francaise, Paris.

COCEAN P. (2002), Geografie regională, Presa Universitară Clujeană, Cluj Napoca.

COFFEY W. (1982), Regional policy in North America, The Canadian Journal of

Regional Science, 2, Regional and Urban Studies Centre, Halifax, p. 225-235.

DAUPHINE A. (1979), Espace, région, système, Ed. Economica, Paris.

DI MEO, GUY (1998), Géographie sociale et territoires, Nathan, Paris.

DRAMOWICZ K. (1985), Some problems of disparities in Poland 's regional development, Geographia Polonica, 51, , Institute of Geography, Warsaw, p. 313-321.

ECKERT D. (1996), Évaluation et prospective des territoires, GIP-Reclus, La Documentation Française, Montpellier-Paris.

ELISSALDE B. (2003), Géographie, temps et changement spatial, L'Espace Géographique, 3, CNRS, Paris p. 224-236.

EPEES (2003), Événement spatial, L'Espace Géographique, 3, CNRS, Paris, p. 193199.

FERRAS R. (1992), Niveaux géographiques, échelles spatiales, Encyclopédie de Géographie, Economica, Paris, p. 403-421.

GAVRELIUC A. (2003), Mentalitate şi societate. Cartografii ale imaginarului identitar în Banatul contemporan, Editura Universității de Vest, Timişoara. New York.

HAGGETT P. (2001), Geography, a global synthesis, Prentice Hall, Horlow-London-

IANOŞ I. (1997), Individualizarea şi analiza disparităților intraregionale. Aplicație la 
județul Alba, Comunicări de Geografie, Editura Universității din Bucureşti, Bucureşti, p. 103110.

IANOŞ I. (2000), Sisteme teritoriale. O abordare geografică, Editura Tehnică, Bucureşti.

IANOŞ I., HUMEAU J.-B. (2000), Teoria sistemelor de aşezări umane. Studiu introductiv, Editura Tehnică, Bucureşti.

JABA E. (1998), Statistica, Editura Economică, Bucureşti.

LEFTER C., CONSTANTIN C. (2009), Economic and social disparities of Romania in Regional and County Profile, Management \& Marketing, vol. 4, no. 1, Transilvania University, Braşov, p. 77-96.

MUNTELE I., GROZA O., ȚURCĂNAŞU G., (2002), Regionarea spațiilor rurale din Moldova în perioada de tranziție. Fundamentul geografic al strategiilor de dezvoltare, in Ungureanu Al., Groza O., Muntele I. (eds.) Moldova, populația, forța de muncă şi aşezările umane în tranziție, Editura Corson, laşi, p. 148-190.

NEUMANN V. (1997), Identități multiple în Europa regiunilor. Interculturalitatea Banatului, Editura Hestia, Timişoara.

NIR D. (1990), Region as a Socio-Environmental System. An Introduction to a Systemic Regional Geography, Kluwer Academic Publisher, Dordrecht/Boston/London.

POPA N. (1999), Definirea conceptului de calitatea vieții, Țara Hațegului. Potențialul de dezvoltare a aşezărilor omeneşti, Editura Brumar, Timişoara, p. 387-389.

RACINE J.-B., (1988), Les nouveaux indicateurs sociaux et spatiaux : qualite de la vie, bien-etre et disparites territoriales, L'Espace geographique, 3, CNRS, Paris, p. 161-165.

REY V., IANOŞ I., PĂTROESCU M., GROZA O. (2002), Atlasul României, Editura Enciclopedia RAO, Bucureşti.

SIRBOVAN C. (1995), Le Banat, archétype de la région multiethnique en Europe,

Sanguin A.- L., Goetschy H., (eds), Langues régionales et relations transfrontalières en Europe, Ed. L'Harmattan, Paris, p. 121-131.

TREBICl V., HRISTACHE I. (1986), Demografia teritorială a României, Editura Academiei, Bucureşti.

VALLEGA A. (1996), The sustainable region: new horizons in regional geography, The geography of disequilibrium. Global isues and restructuring in Italy, Italian Society of Geography, Rome, p. 13-38.

WATSON M.K. (1978), The Scale Problem in Human Geography, Geografiska Annaler, vol. 1, 60 B, Blacwell Publishing, p.36-47.

WALLERSTEIN I. (1998), The Time Of Space And The Space Of Time/ The Future Of Social Science, Political Geography, 1, p. 71-82.

* * * General Census of Population and Housing, 1992, 2002, INSSE, Bucureşti.

Received at : 15.10 .2010

Revised at: 23.11.2010

Accepted for publication at: 10.12.2010 